\title{
All Fall Down: The Demise of the New Dance Group and the "Highest" Stage of Communism
}

\section{VICTORIA PHILLIPS GEDULD*}

In February 2009, the New Dance Group (NDG) closed its doors after 77 years. ${ }^{1}$ The New York Times obituary reported that the group was founded in the Depression by choreographers who produced works with a "populist or activist bent" - an understatement typical of NDG history. The six radical women who created the group on New York City's Lower East Side in 1932 envisioned it as a vehicle for "developing and creating group and mass dances expressive of the working class and its revolutionary upsurge.", In 1931 after members of the radical artistic intelligentsia returned from a World Plenum in Kharkov, Russia, a newly formed Workers Cultural Federation announced, "Art is a Weapon."3

${ }^{\star}$ This work could not have been written without Elizabeth Aldrich, Curator of Dance, Music Division, Library of Congress. Her dedication to the preservation of collections, her meticulous attention to details, as well as her sense of humour and keen understanding of history made her an invaluable partner. In addition, the work could not have been completed without the support of Ph.D. candidates at Columbia University's Dept. of History: Jessica Adler, Mike Woodsworth, and Thai Jones. Encouraged by the faculty, particularly Eric Foner and Lynn Garafola, we have learned that sharing editing skills, resources and archival knowledge only makes us stronger scholars in our own fields. Dan Leab's bravery, kindness and support of new scholarship inspired this work. I alone accept responsibility for all errors. Email:LVB3@columbia.edu

${ }^{1}$ Daniel J. Wakin, compiled by Dave Itzkoff, "New Dance Group Closes," New York Times, 13 February 2009.

2 "New Dance Group First Anniversary Recital," Programs-1933. At the time of publication, the NDG Collection and the NDG Legacy Collection were both in the process of being archived at the Library of Congress, Music Division, Washington, DC. Thus the addition of box and folder numbers was not possible in citations. The information provided, however, should lead a researcher to the documents in the collection through a detailed Finding Aid forthcoming in 2010. For further guidance on the footnotes or research, please contact the author.

${ }^{3}$ Harvey Klehr, The Heyday of American Communism: The Depression Decade (New York: Basic Books, 1984), 73; "Report of the conference that Organized the Workers Cultural Federation of the New York District," reel 194, delo 2579 (Communist Party of the US of America (CPUSA) Archives, Elmer Holmes Bobst Library, Tamiment Library and Robert F. Wagner Archives, New York University (hereafter CPUSA archives)); "Art is a Weapon: Program of the Workers Cultural Federation," New Masses, August 1931, 11-13. 
The first annual 1933 NDG bulletin declared, "Dance is a Weapon.", Following themes proposed by the Agit-Prop Department of the Communist Party of America (CPUSA) and suggested in Workers Theatre magazine, the choreographic collective produced works such as fingoisms, Strike and Parasite (c. 1932-1933). The NDG school boasted 300 students who studied Marxism after dance classes as a part of the school's mandatory curriculum. ${ }^{5}$ The euphemistic 2009 Times eulogy did not even use the word "leftist" — which seems doomed to remain a slur. Given the NDG's revolutionary roots, its financial ruin might not appear surprising after the seeming twentieth century triumph of American capitalism.

Between 1933 and the 1950s, the organization and choreographic themes of NDG mutated. The NDG choreographic collective group presented Van der Lubbe s Head (1934), which protested the execution by beheading of the Dutch communist who served as a scapegoat for the burning in March 1933 of Germany's Reichstag building in Berlin. As the collective influence dissipated at NDG and the individual choreographers claimed credit for their work, Sophie Maslow performed May Day March (1936) and Three Songs About Lenin (c. 1935) later performed as Two Songs About Lenin (c. 1938). Other individually constructed dancers protested sharecropping (Harmonica Breakdown, Jane Dudley, 1938), and homelessness (Tenant of the Street, Eve Gentry, 1938). In 1940 the group performed its last collectively created dance, ironically titled Survival of the Fittest.

After the Nazi-Soviet Pact severed already tenuous NDG connections to the CPUSA, choreographers remained committed to leftist social tenets while supporting the nation. They protested lynching with two separate productions of Strange Fruit, one by Jerome Robbins (1940) and the other choreographed by Pearl Primus (1943) danced to communist Abe Meeropol's poem. ${ }^{6}$ During World War II, the group offered free classes to soldiers and Dudley choreographed a work to support the "Double V" campaign which sought to achieve victories over the international Axis powers and domestic racial prejudice. After the war, NDG celebrated racial integration with Donald McKayle's Games in 1951, the year that many credit as the beginning of the transition from the "old left" Marxists to a youth coalition that would lead the Civil Rights movement in the 1950s and 1960s. ${ }^{7}$ In the decade after the end of World War II NDG evolved from a choreographic collective into a conglomeration of individual choreographers who shared ideologies. Despite its political leanings, by 1955 NDG became firmly entrenched in the capitalist financial system: the group, turned corporation, purchased a building. Former CP

\footnotetext{
4 "New Dance Group First Anniversary Recital."

${ }^{5}$ Ellen Graff, Stepping Left: Dance and Politics in New York City, 1928-1942 (Raleigh Durham, NC: Duke University Press, 1997; reprint 1999), 55; "New Dance Group First Anniversary Recital."

${ }^{6}$ Strange Fruit, Jerome Robbins and Anita Alvarez, Heckscher Theatre, 19 May 1940, Programs, 1940.

${ }^{7}$ Programs, 1933-1955; Philip A. Klinkner, The Unsteady March: The Rise and Decline of Racial Equality in America (Chicago, IL: University of Chicago Press, 1999), 231-232.
} 
member Jane Dudley signed the deed on behalf of NDG. ${ }^{8}$ The institutional transition from communal membership to individual ownership had begun.

By 2001, mortgage financing for the NDG building had been ploughed into the stock market by a small Board, signalling the first of several moves that would be investigated by the Attorney General of New York. ${ }^{9}$ In the same year, as a part of a gala celebration, Vice-President Dick Cheney wrote a letter to congratulate NDG on its "long history of service to the artistic communities and developing several generations of modern dance masters."10 Cheney singled out honourees-who had long left NDG-including choreographer Jane Dudley, whose FBI file detailed her activities and her husband's blacklisted status through 1961. ${ }^{11}$ After the old Left met the new political Right, NDG imploded as it followed the downward spiral of American capitalism in the twenty-first century.

As time passed during the Cold War, the choreographers increasingly embraced individualism. NDG members began to market themselves as individuals while they performed under the NDG umbrella. Like mainstream choreographers such as Martha Graham, even NDG stalwart Sophie Maslow named her company for herself. For funders, collectives had no cachet. Whether brokering relationships with television producers to perform on Look up and Live and Lamp unto My Feet, or getting university appointments and performing under the auspices of domestic government programs, each choreographer benefitted by presenting works as part of a company with a distinct style and repertory.

The organization of NDG followed the move towards individualism, albeit in baby steps. Despite the fracturing of a choreographic collective, the ideology of sharing space cooperatively was documented in voluminous pages of meeting minutes from 1955 through the 1970s. Earlier members of the group remained on the Board of Directors, including Sophie Maslow, Pearl Primus and Donald McKayle. Yet by the 1980s most of the dancers had departed to start independent studios and companies, with the exception of Sophie Maslow who remained on the Board. ${ }^{12}$ In 1984, however, the structure of the corporation was changed to eliminate "members" who had largely been choreographers and dancers, thus granting full governing powers to the reconstructed Board

\footnotetext{
8 "Deed of Sale" (copy dated 30 June 1986), 11 February 1955, Business Papers, Building, 247 West 47th Street.

9 "'Exhibit: To Board of Directors, From Rick Schussel, 2 December 1988. Re: Investments,” 2, Elliot Spitzer v. Rick Schussel et al. Index \#401871/2006, Legal, New York State Attorney General Investigation, 2003-2007 (hereafter AGI); Business Papers, Financial, PaineWebber Statements. The investment policy discussion began, "As per our discussions, I have drafted an investment policy for the use of all investment funds. We will use the policy on the closing date of the mortgage agreement closing with National Bank of New York scheduled for 11 December 1998."

10 "To New Dance Group Arts Center, From Dick Cheney," on Office of the Vice-President stationary, 12 September 2001, Business Papers, Fundraising, 70th Anniversary Gala.

${ }^{11}$ Federal Bureau of Investigation, Name Files, Jane Dudley, New Dance Group Legacy Collection, Music Division, Library of Congress, Washington, DC.

${ }^{12}$ Board Meeting Minutes, 1987-1989.
} 
of Directors. ${ }^{13}$ Despite protests by Maslow, the Board passed a motion that required all Board members to donate $\$ 2,000$ per year, which Maslow called "a heinous habit of buying one's way onto a board."1

Those who could not contribute were removed. ${ }^{15}$ Maslow and other remaining dancers did not have the money to continue on the Board. ${ }^{16}$ Although some programs continued, particularly for children, income was derived from studio rentals, and the NDG's headquarters became an ideologically declining asset. Board meetings became monthly, quarterly, and then even bi-yearly. As a corporation, NDG struggled to find programs or earn rental income that would cover expenses, much less make profits. During this prolonged struggle, NDG took mortgages on the building and invested funds in the stock market.

The Communist tenets that NDG members studied in the 1930s proved to be ironically prophetic. Its financial ruin worked in lock-step with the US economy, yet turned NDG's formative ideology on its head. V.I. Lenin argues in Imperialism: The Highest Stage of Capitalism (1917) that its final stages would include "balance-sheet jugglery." ${ }^{17} \mathrm{He}$ described the demise of capitalism using the example of General Electric's balance sheet manipulations, foreshadowing the billion dollar bailout of GE Capital by the US government some 90 years later due to the crisis caused by the collapse of mortgage-backed securities. Pushing directly into the history of NDG, its financial statements show that GE was one of over 50 stocks included in NDG's Smith Barney brockerage account, funded by the mortgage on the NDG building. ${ }^{18}$ Yet Lenin's theories become twisted by the story of NDG's collapse: it slid from communist-inspired programs, to choreography expressing socialist ideals that became immersed in American capitalism in order to survive financially, and then entered its final stage of capitalism with mortgage financing to manipulate assets for personal gain, only to leave the system morally and financially bankrupt. Under NDG, capitalism's excesses became the highest stage of communism. Indeed, what Lenin called "jugglery" eventually brought the Communist-seeded NDG to its knees.

The specific blows to NDG's solvency began in the early 1980s. In 1983, dancer Rick Schussel joined the Board as heated discussions about financial issues resulted in a demand for new blood. ${ }^{19}$ In 1984 he became Co-Treasurer and then Treasurer. Despite misgivings expressed by longstanding Board members, he began a serious investigation of loans and eventually mortgages for

\footnotetext{
${ }^{13}$ Board Meeting Minutes, 26 June 1984. The resolution, which passed on 11 July 1984, shows the "membership structure dissolved" and "all management decisions become the responsibility of the Board of Directors."

${ }^{14}$ Board Meeting Minutes, 30 September 1987.

${ }^{15}$ Board Meeting Minutes, 30 September 1987.

${ }^{16}$ Board Meeting Minutes, 19 December 1989; Author interview with Muriel Manings, 2007.

${ }^{17}$ V.I. Lenin, Imperialism: The Highest Stage of Capitalism (New York: International Publishers; reprint 2004), 49.

${ }^{18}$ Business Papers, Financial Statements, Smith Barney Account Statements.

${ }^{19}$ Board Meeting Minutes, Ad Hoc Meeting, 2 November 1983. Rick Schussel is noted as "Present" with "New Board Member" added after his name.
} 
the building because income continually failed to meet expenses. ${ }^{20}$ By 1986 Schussel emerged as Artistic Director as well as Treasurer. Raising money through debt obligations while deferring his executive compensation expenses to long-term liabilities, the building mortgage increased, and Schussel began loaning NDG money that accrued at an average of over $11 \% .^{21}$

The balance sheet's liabilities escalated exponentially and reporting problems began. NDG could not pay Schussel cash interest from income and thus much of the interest due, as well as Schussel's salary, were added to the long-term loan principal amount. Pictures of the facilities and citations from various City agencies show that the studios and the building were crumbling. ${ }^{22}$ A fire weakened the structure. ${ }^{23}$ By 1996, audits by the accounting firm showed discrepancies between the books kept by NDG and the audited financials, and final results were delayed. ${ }^{24}$ After disputes in 1999, NDG switched accounting firms and they restated prior years' results downwards. ${ }^{25}$

As non-cash liabilities increased at NDG, the Board approved the use of cash received from mortgages to explore investment opportunities rather than for capital expenditures, such as building repairs. Meeting minutes reported on a new mortgage loan, with a majority of the cash going into a PaineWebber brokerage account overseen by Schussel. ${ }^{26}$ In 2002, the PaineWebber account was closed "due to Paine[W]ebber losing all our monies." 27 NDG promptly sued PaineWebber and opened a Morgan Stanley account. ${ }^{28}$

As the Board took on new mortgages, a Smith Barney account was opened. ${ }^{29}$ The Board authorized an investment policy that allowed Schussel to oversee the

\footnotetext{
${ }^{20}$ Board Meeting Minutes, 10 April 1984, 19 June 1984, 1 September 1985.

21 “Calculation of Interest after Personal Expenses-For Settlement Purposes [re loans] 09/01/199805/31/2005, Miscellaneous Summaries," files contain handwritten annotations, Business Papers Loans and Exchanges; "Supreme Court of the State of New York, County of New York, Eliot Spitzer, Attorney General of New York, against Rick Schussel, Ivan Dall, Glen Schneiderman, Nadine Tomlinson, and Arthur T. Wilson, individually and as Trustees of the New Dance Group Studio Inc., a/k/a The New Dance Group Arts Center, IAS Part 24, Index No.: 401871/2004, "National Bank of New York, 31 August 2003, Document \#9624323," dates mortgage \#1 on 17 March 1988 at \$150,000, section 4, exhibit B. Mortgages 1, 2, 3, 4, 5 are consolidated 16 April 2003 to $\$ 1.941 \mathrm{~m}$, AGI.

${ }^{22}$ Pictures, Building, 254 West 47th Street; Business Papers, City Violations, 1970-1990; Business Papers, City of New York, Office of the Marshall, 1990s; Business Papers, Environmental Control Board, 1988-1991; To Rick Schussel, from Coastal Abstract, Service, inc., Re: CA7692, 29 June 1994, Business Papers, Building Violations, 244 West 47th.

${ }^{23}$ Business Papers, Fire.

${ }^{24}$ Board Meeting Minutes, 1 November 1996.

${ }^{25}$ Board Meeting Minutes, 17 October 1996, 1 November 1996, and 12 December 1996 (reported profit of $\$ 50,000$ becomes $\$ 10-15,000)$. On 10 December 1999 a dispute with the accountant regarding 1998 statements led to the firing of BDOS. The new accounting firm restated FY 1998 and 1999, Business Papers, Financial, Audited Statements, 1990-2000.

26 “"Exhibit: To Board of Directors, From Rick Schussel, 2 December 1988 Re: Investments;” Board Meeting Minutes, typewritten 19 November 1999, pencil edited, April 2000/1, 3 August 2001, 15 March 2002, 25 October 2002.

${ }^{27}$ Board Meeting Minutes, 15 March 2002.

${ }^{28}$ Board Meeting Minutes, 20 January 2003.

29 “Exhibit 24," Eliot Spitzer v RS et al. Index \#401871/2006, AGI-NDGC. 30 September 2006 shows Smith Barney account opened with funds from mortgage closing, and Smith Barney account with a balance of $\$ 3.315 \mathrm{~m}$., AGI and Business Papers, Financial.
} 
trading in brokerage accounts, with "formal yet flexible investment guidelines." ${ }^{30}$ Indeed, notes indicate that some stocks were considered for margin trades, thus possibly incurring the highest stock market risk allowed by law. ${ }^{31}$ With rising real estate values in New York City and the decline of the NDG facility, the Board began to consider the sale of the building in order to pay off long-term obligations for mortgages and the "Loan to Director," or Schussel.

All financial activities were fully approved by the Board that consisted of as few as five members, with three present at meetings, including Schussel and his wife. ${ }^{32}$ Although the minimum yearly contribution required for Board membership escalated to $\$ 10,000$ from the earlier $\$ 2,000$, a proposal exempted Schussel and his wife in recognition their "time, effort, and dedication." 33 If Maslow had been offered this same courtesy, she would have remained on the Board as she protested the assumption of mortgage debt financing. Schussel was named Curator and Superintendent of the building and took dance studio space as his apartment. As the building was readied for sale in 2000, Schussel's moving expenses plus $\$ 36,000 /$ year for his family's rental expenses were authorized by the Board. ${ }^{34}$ Although certainly no corporate jet, a wood-sided NDG station wagon moved the Artistic Director around town; expenses included payments for the garage, EZPass and parking tickets. ${ }^{35}$ The Board offered Schussel 5\% of the total sale price of the building, once sold, as well as repayment of his loans. ${ }^{36}$

Yet by 2003 New York Attorney General Eliot Spitzer's Charities Division had begun an investigation of NDG due to "allegations of various breaches of fiduciary duty by the NDG Board of Directors." 37 Although Schussel claimed that the Assistant Attorney General in charge of the investigation "does not understand the master plan," the office questioned loans from Schussel and his parents, and alleged that the Board had approved numerous questionable expenses for food, travel to Europe, housing and the car. ${ }^{38}$

By 2004, the building sale plans grew frenzied and the total loan amount owed to Schussel stood at over $\$ 1.3$ million. ${ }^{39}$ In the same year, Schussel came close to closing a sale for $\$ 9.27$ million that could have reaped the Artistic Director over $\$ 2.2$ million in addition to the $\$ 1.3$ million owed. The plans fell through. In 2005 the Attorney General's office oversaw the building sale for

\footnotetext{
30 "Exhibit: To Board of Directors, From Rick Schussel, 2 December 1988 RE: Investments"; Elliot Spitzer v Rick Schussel et al. Index \#401871/2006, AGI.

31 "Investing System" [nd] shows an accounting of trading in shares of Altera and Rambus margined at $50 \%$, Business Papers, Financial, Miscl. Notes. Due to stock splits, the price of the shares indicated by the spreadsheet cannot accurately date the transactions.

${ }^{32}$ Eliot Spitzer v RS et al. Index \#401871/2006.

${ }^{33}$ Board Meeting Minutes, Amendment to B-Laws, 1 November 1996.

${ }^{34}$ Board Meeting Minutes, 14 July 2000.

${ }^{35}$ Pictures, NDG Car; Business Papers, Financial, Car; Business Papers, Financial, Parking Violations, 1990-1993; Business Papers, Financial, Parking Violations, Pictures, Car.

36 "'Statement of Closing, 20 January 2006," AGI.

37 "IAS Part 24, Index No.: 401871/2004," AGI.

${ }^{38}$ Name Files, Rick Schussel, Notes.

39 "Cash out of New Dance in other ways [09/01/2002-08/31/2003]," Business Papers, Loans and Exchanges; Name Files, Rick Schussel, Business Papers, Loans and Exchanges.
} 
just over $\$ 7$ million and mandated a budget for the construction of new rental space. Repeated calls by the Attorney General's office for an accounting of spending for the new rental space went unanswered: little changed at NDG. ${ }^{40}$

After numerous complaints and appeals, a 14-point agreement was signed in 2008. ${ }^{41}$ Schussel was barred from the Board and from engaging in financial transactions at the Board level, but he remained Artistic Director and received a $\$ 1.2$ million settlement. ${ }^{42}$ The Attorney General searched for appointees to constitute a newly reconstructed Board. Despite attempts at oversight, according to letters from the Attorney General's office funds were squandered during the restructuring period. ${ }^{43}$

As Artistic Director, Schussel had plans that showed promise, yet he combined the worst of financial capitalism with a twisted version of artistic socialism. Schussel did not overlook the wealth of the NDG choreographic legacy, even amidst all the financial wizardry, mortgage refinancings, brokers' account failures, an oddball car, and board-approved deals. Indeed, to gain access to the early dance treasures Schussel interpreted the Group's socialist roots as a means by which to challenge questions of choreographic ownership. Claiming that the group's beginnings as a collective allowed him the rights to all the dances created in the NDG studios from inception, he began considering classic masterworks for performances by a new NDG performing unit. ${ }^{44}$ The 75th Anniversary Gala in 2007 marked the debut of a company which would perform earlier dances by choreographers who worked at NDG alongside new political works choreographed under the direction of Schussel.

The choreographed classic dances under consideration included undetermined pieces by Jerome Robbins and also Donald McKayle's Games, which would be revived at American Dance Festival under the watchful eye of McKayle himself. ${ }^{45}$ Schussel began rehearsing Dudley's Harmonica Breakdown and Maslow's works without the knowledge of the legal heirs. They caught wind of the rehearsals, and Schussel was barred from presenting the works unless he entered a binding licensing agreement. ${ }^{46}$

Yet he did not entirely cease or desist. In 1993, Schussel had obtained permission to mount Eve Gentry's Tenant of the Street under the stipulation that the heir, recognized as such by Schussel, would teach the work and approve all casting. ${ }^{47}$ No contract was signed. But at the 2007 gala Schussel presented Gentry's choreography without oversight or a contract. An NDG film of the

\footnotetext{
${ }^{40}$ Business Papers, Correspondence, Legal.

41 "'Stipulation of Settlement," AGI.

42 "Stipulation of Settlement."

${ }^{43}$ Business Papers, Correspondence, Legal.

${ }^{44}$ Business Papers, Fundraising, 75th Anniversary Gala, Rick Schussel Notes; Schussel interview with author, 2007, NDG Studios, author's meeting notes with Cravath Swaine and Moore, LLP available upon request.

${ }^{45}$ Business Papers, Fundraising, 75th anniversary Gala, Rick Schussel Notes; http://www. americaudancefestival.org/history/adfTiraeline.html (1 November 2009).

${ }^{46}$ From Katherine Forrest, Cravath Swaine and Moore, LLP, 1 June 2007, Business Papers, Legal.

${ }^{47}$ Business Papers, Fundraising, 75th Anniversary Gala, Rick Schussel Notes.
} 
gala performance of Tenant of the Street appeared on NDG's Facebook and on You Tube. NDG titled the work Bag Lady of Today. ${ }^{48}$

Schussel continually imagined new choreographic programmes that could spring from the NDG dance legacy. A suggestion considered by Schussel included a work in which "liberals and conservatives [would come] together and we hope it will be very inspiring to see the likes of Michael Moore or Ann Coulter move in unison - not in a titillating 'Dance with the Stars' way but in a highly artistic fashion." 49 Perhaps protesting his own sense of injustice as the Internal Revenue Service investigated Schussel after his $\$ 1.2 \mathrm{~m}$ settlement with the Attorney General, the choreographer envisioned a work titled Government Interference: But I'm Dancing on Eternity. ${ }^{50} \mathrm{He}$ noted, "The piece centers around the government's continued efforts to interfere with the creative process." 51

Lenin's prediction that balance sheet wizardry would bring the end of an era came to fruition with mortgage financing and stock market ventures for both American corporations and NDG. Pundits rationalize recent government bailouts of banks and companies under the rubric, "Too big to fail." NDG is a parable of contradictions. The choreographers and their companies do not merit government attention. In October 2009, a production of Mary Anthony's The Devil in Massachusetts, a work presented through NDG that protested the House on Un-American Activities tactics in the early 1950s, was cancelled due to lack of funding. The company needed only $\$ 10,000 .^{53}$ Are these potent works and the companies that reconstruct them judged to be "too small to succeed"?

Despite NDG's financial implosion, many of the tenets that formed NDG's early ideological base have endured. As Anthony remarked in 2006, "We were not communists; we just believed everything they believed."54 The NDG

\footnotetext{
${ }^{48}$ Name Files, Eve Gentry; Business Papers, 75th Anniversary Gala, NDG; "Bag Lady of Today," posted 25 July 2008, http://www.facebook.com/pages/New-Dance-Group/38354233528; http:// www.youtube.com/watch?v=vj1JzloQCq0\&feature=channel_page (18 July 2010).

${ }^{49}$ Choreographic Notes, Name files, Rick Schussel.

${ }^{50}$ Board Meeting Minutes, 27 October 2008. "Mr. Schussel expressed some speculations that ... the personal case opened against him and Mr. Jae McManus, previous NDG General Manager, are all connected to the AG investigation. Jamie Gavrin raised that issue of possible conflict arising from the IRS cases and the necessity of keeping the NDG and Mr. Schussel's cases separate and represented by separate councils."

${ }^{51}$ Choreographic Notes, Name files, Rick Schussel; Business Papers, Fundraising, 70th Anniversary Gala.

${ }^{52}$ Andrew Ross Sorkin, Too Big to Fail: The Inside Story of Wall Street (New York: Viking, 2009).

${ }^{53}$ Elizabeth McPherson, " $360^{\circ}$ Dance Company: 'Night Journey,' 'Maktub' and 'The Devil in Massachusetts',” Ballet-Dance Magazine 9 May 2009, http://ballet-dance.com/200906/articles/ 360 aileystudios 20090509 mcpherson.html (2 October 2009); 360 Dance Company, Martin Løfsnes, Artistic Director, cancelled November 2009 performances including The Devil in Massachusetts at the Alvin Ailey Theater, New York City, due to lack of funding. Note that through private funding the work will be seen at the Dance Theatre Workshop for three performances in June 2010.

${ }^{54}$ Mary Anthony, "Oral History with Mary Anthony”, interview by Victoria Phillips Geduld, 2 August 2006, NYC, Columbia University Oral-History Research Office, transcript closed but available upon request.
} 
choreographers, as a collective of individuals, stood for social justice throughout their careers. They supported many radical causes through their choreography, well before such causes were accepted by most Americans. Although financial greed has closed NDG's doors, its ideological roots represent the enduring and home-grown power of protest and political action. 
Copyright of American Communist History is the property of Routledge and its content may not be copied or emailed to multiple sites or posted to a listserv without the copyright holder's express written permission.

However, users may print, download, or email articles for individual use. 